\title{
WINTER STREAM CONDITIONS AND USE OF HABITAT BY BROOK TROUT IN HIGH-ELEVATION WYOMING STREAMS
}

I.A. Chisholm, W.A. Hubert and T.A. Wesche

Journal Article WRRC-87-26

\section{Transactions of the American Fisheries Society}

\author{
Ian Chisholm \\ Montana Department of Fish, Wildlife and Parks \\ Libby, Montana
}

\author{
T.A. Wesche \\ Wyoming Water Research Center \\ University of Wyoming \\ Laramie, Wyoming
}

W.A. Hubert

Wyoming Cooperative Fishery \& Wildlife Research Unit University of Wyoming

Laramie, Wyoming 
LRH: CHISHOLM ET AL.

RRH: WINTER HABITAT USE BY BROOK TROUT ?. Cransactions of the American Fisheries Society 000:000-000, 0000

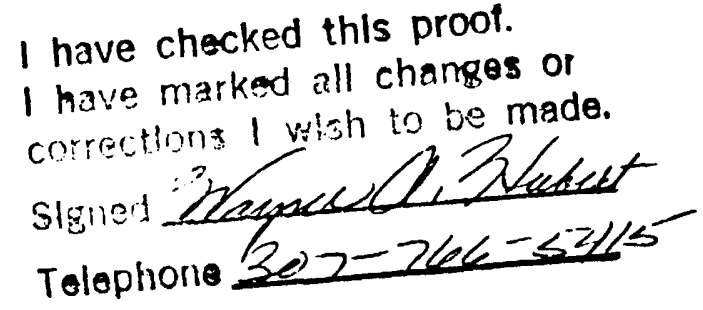

\title{
Winter Stream Conditions and Use of Habitat by Brook Trout in High-Elevation Wyoming Streams
}

\author{
IAN M. Chisholm ${ }^{1}$ and Wayne A. Hubert \\ Wyoming Cooperative Fishery and W'ildlife Research Unit, ${ }^{2}$ University of Wyoming \\ Laramie, Wyoming 82071 . USA \\ Thomas A. WeSCHE \\ Wyoming Water Research Center, University of Wyoming
}

\begin{abstract}
Winter stream conditions at elevations between 2,280 and $3,205 \mathrm{~m}$ above mean sea level and the use of winter habitat by adult brook trout Salvelinus fontinalis above $2,990 \mathrm{~m}$ were evaluated in 1983-1984 and 1984-1985. Little surface ice was observed at elevations above 2,900 $\mathrm{m}$, which was associated with high snow accumulation; moderate surface ice and anchor ice formation were observed at elevations from 2,550 to $2,900 \mathrm{~m}$; extensive surface ice formation occurred at $2,550 \mathrm{~m}$. Little snow accumulated at $2,550 \mathrm{~m}$ and surface ice physically excluded substantial brook trout habitat. In late fall, brook trout at elevations above $2,990 \mathrm{~m}$ tended to move into low-gradient arez where they remained active throughout the winter. During winter, brook trout appeared to select for areas with maximum velocities of $15 \mathrm{~cm} / \mathrm{s}$ or less, measured during summer low flow, and for deeper water, but not for substrate type.
\end{abstract}

Winter conditions have been recognized as limiting trout populations in streams, and overwinter mortality has been identified as a factor determining trout production. Despite this, research, either on winter stream conditions encountered by trout or on their winter requirements, is limited.

Past research has examined the effects of ice and snow cover on trout and macroinvertebrates in streams. Needham and Slater (1944) and Needham et al. (1945) attributed a portion of overwinter trout mortality to habitat conditions, especially collapsing snow banks. Maciolek and Needham (1952) reported trout mortality caused by dewatering that resulted from subsurface blockage of streamflow by ice. Reimers (1957) and Needham and Jones (1959) concluded that mortality of rainbow trout Salmo gairdneri during winter was caused mainly by snow and ice and not by a lack of food or by prolonged low water temperatures.

Winter habitat selection and movement of trout have also been studied, and findings have been contradictory. Declining water temperatures trigger downstream movement of some salmonids from tributaries into larger streams, where the fish

\footnotetext{
'Present address: Montana Department of Fish, Wildlife and Parks, Route 1, Box 1270, Libby, Montana 59923, USA.

${ }^{2}$ The unit is jointly supported by the University of Wyoming, the Wyoming Game and Fish Department, and the U.S. Fish and Wildlife Service.
}

overwinter (Chapman and Bjornn 1969; Hynes 1970). Adult brook trout Salvelinus fontinalis migrate upstream to spawning areas during fall and then downstream to deeper water during winter; juvenile brook trout move predominantly downstream (McFadden 1961; Hunt 1969, 1974). Hunt (1974) observed that, in fall, downstream movement of young and adult brook trout decreased after habitat improvement work increased pool area and stream-bank hiding cover in areas where the brook trout lived in summer. Bjornn (1971) noted a lack of brook trout fry migration and speculated that the fish would not move if populations did not exceed the winter cover capacity of the stream. Benson (1955) found brook trout in quiet eddies and under banks during winter. Cooper (1953) reported that brook trout deserted the pools occupied from spring to fall and moved to areas of dense cover in winter.

Despite the array of winter habitat research on brook trout, no studies have focused on the extent of winter movement or the specific habitat features selected, including current velocity, water depth, and substrate. No studies have been conducted on winter conditions in high mountain streams, where large amounts of snow accumulate. We undertook this work with three objectives: (1) to describe winter habitat conditions on streams at elevations above $2,280 \mathrm{~m}$ mean sea level in southeastern Wyoming; (2) to determine the influence of decreasing elevation on winter habitat conditions; and (3) to examine winter use 


\section{PROARS ANB MANUSCRIPT

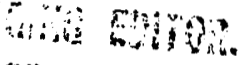 \\ I OROER TO ALLEN PRESS.}

of stream habitats by brook trout at elevations above $2,900 \mathrm{~m}$.

\section{Study Area}

Two study reaches were selected at elevations between 2,993 and $3,205 \mathrm{~m}$ on each of two streams - Telephone Creek and Nash Fork Creeklocated on the east slope of the Snowy Range in the Medicine Bow National Forest, Albany County, Wyoming (Table 1$)$. Water temperatures $(0.0$ $\left.1.0^{\circ} \mathrm{C}\right), \mathrm{pH}(7-8)$, total alkalinity $(24-34 \mathrm{mg} / \mathrm{L})$, and hardness $(68-94 \mathrm{mg} / \mathrm{L})$ were similar among the four study reaches in winter (January-March) 1985. The watersheds are used for timber production, livestock grazing, and recreation. Riparian areas were alpine meadows dominated by willows Salix spp., sedges Carex spp., and grasses. Upland areas were primarily spruce Picea sp. and fir Abies sp., mixed with lodgepole pine Pinus contorta at lower elevations. Mean annual precipitation in the vicinity of the study area is about $100 \mathrm{~cm}, 80 \%$ of which falls as snow between October and May. Streams in the watershed have discharge patterns typical of those in the central Rocky Mountains-low flows from late fall until spring, after which snowmelt causes peak runoff (Wesche 1982). During our winter study periods, flows through the four reaches typically ranged well below $0.5 \mathrm{~m}^{3} / \mathrm{s}$.

Nine additional study reaches were established on the same stream system between 2,280 and $2,868 \mathrm{~m}$ to investigate differences in stream conditions at lower elevations. These study reaches

TABLE 1. - Biological and hydrological characteristics of the Snowy Range, Wyoming, study sites, September 1983 to February 1985.

\begin{tabular}{|c|c|c|c|c|c|}
\hline $\begin{array}{l}\text { Stream, } \\
\text { reach }\end{array}$ & $\begin{array}{c}\text { Biomass" } \\
\text { (kg/hect- } \\
\text { are) }\end{array}$ & $\begin{array}{c}\text { Eleva- } \\
\text { tion } \\
(\mathrm{m})\end{array}$ & $\begin{array}{l}\text { Mean } \\
\text { wet- } \\
\text { ted } \\
\text { width } \\
\text { (m) }\end{array}$ & $\begin{array}{c}\text { Mean daily } \\
\text { discharge } \\
\text { rangeb } \\
\left(\mathrm{m}^{3} / \mathrm{s}\right)\end{array}$ & $\begin{array}{c}\text { Stream } \\
\text { order } \\
\text { at study } \\
\text { reache }\end{array}$ \\
\hline \multicolumn{6}{|l|}{ Telephone Creek } \\
\hline Upstream & 318 & 3.205 & 2.2 & $0.01-0.78$ & 2 \\
\hline $\begin{array}{c}\text { Downstream } \\
\text { Nash Fork Creek }\end{array}$ & 106 & 3.150 & 4.0 & $0.01-0.99$ & 2 \\
\hline Upstream & 189 & 3,120 & 3.0 & $0.02-1.14$ & 2 \\
\hline Downstream & 125 & 2,993 & 5.1 & $0.04-2.44$ & 3 \\
\hline
\end{tabular}

- All fish were brook trout except in downstream Nash Fork Creek ( $54 \%$ brook trout, $46 \%$ brown trout). No other fish species were captured.

b Means of measurements from October 1969 to September 1984.

c Stream order was measured from solid blue-line streams on 1:64,000 scale contour maps (U.S. Geological Survey, Washingion, D.C.).
Fish. Trans. $-700-B$. . 8526F ... Gal. 21

were on Nash Fork Creek, Libby Creek, the North Fork of the Little Laramie River, and the Little Laramie River-all on the eastern slope of the Snowy Range in Albany County, Wyoming. Criteria for selection of the reaches were the presence of an identifiable riffle-pool sequence, a reach gradient similar to those in reaches in high-altitude meadows $(<1.5 \%)$, and the presence of a brook trout population.

\section{Methods}

Stream habitat. -At each of the four high-elevation reaches, three permanent transects were established in September 1983 to provide an index of stream habitat conditions through the winter. Transects were perpendicular to streamflow and crossed three types of habitat - a riffle, a transition area between a riffie and a pool, and a pool. Stream characteristics were measured at each transect seven or eight times between September 1983 and April 1984. Water temperature was measured on each visit with a hand-held thermometer. Other variables measured were water depth, ice depth, snow depth, distance between the water surface and snow or ice (air gap), width of wetted surface, and wetted perimeter. Wetted perimeter is the length of the wetted contact between a stream of flowing water and its containing channel measured in a plane at right angles to the direction of flow (Rechard et al. 1975).

At least 10 measurements were made along each transect. Transect monitoring followed this procedure: (1) snow between stakes marking the transect was removed to create a trench $0.6-1.0 \mathrm{~m}$ wide; (2) snow (and ice if present) was removed from the stream; (3) a measuring tape was stretched between permanent survey stakes from left bank to right bank; (4) water depth, ice depth, and air gaps were measured to the nearest $1.5,3$, and 3 $\mathrm{cm}$, respectively; (5) snow depth was measured to the nearest $3 \mathrm{~cm}$ at the left bank, at mid-stream, and at the right bank when snow cover was complete, and at the same intervals as ice depth when incomplete; and (6) the trench was refilled with snow. Discharge data were obtained from nearby stream gage stations maintained by the Wyoming Water Research Center.

The physical conditions measured at riffle, pool, and transition transects in 1983-1984 were measured in the same fashion once again at all 13 study reaches during January 1985 to assess variation associated with differences in altitude. The same transects were used in 1983-1984 and 1984 1985 at the four high-elevation reaches. In addi- 
tion, discharge was measured in January 1985 at each study reach by the method of Buchanan and Somers (1969).

As part of our habitat evaluation procedures, we made fish population estimates at each of the four high-altitude study reaches in September 1983 and July 1984 by electrofishing, using the threepass removal method (Zippin 1958). Study reaches were 40-90 m long and were isolated with block nets prior to electrofishing.

Habitat use and movement. - Habitat use by and movement of brook trout were investigated by means of radiotelemetry. Transmitters measured $2.5 \times 1.5 \mathrm{~cm}$, weighed $5-6 \mathrm{~g}$ in air, were neutrally buoyant in water, and had a pulse rate of $30 / \mathrm{min}$. We surgically implanted the transmitters into the body cavities of brook trout captured by electrofishing, following the general procedures of Hart and Summerfelt (1975). Fish were held in fresh stream water from 5 to $15 \mathrm{~min}$ after equilibrium was regained before they were released at the point of capture.

A 49-MHz receiver and loop antenna (Custom Telemetry, Athens, Georgia) were used to receive transmitter signals and identify fish locations. The radio-tagged fish were located to within 0.6-1.2 $\mathrm{m}$ of their position twice per week. Fish locations were referenced by streamside landmarks, by triangulation with a compass, and by distances measured with a surveyor's tape.

In October 1983, eight adults (182-227 $\mathrm{mm}$ total length, TL) were implanted with transmitters, two fish from each of the four study reaches above $2,990 \mathrm{~m}$. Those fish were among the largest to be found in the study streams. All were captured and released in low-gradient $(<1.5 \%)$ meadow areas. To assess the importance of low-gradient areas, we repeated the process with eight other fish (215$226 \mathrm{~mm} \mathrm{TL}$ ) in October 1984 in a high gradient reach (>4\%) of Nash Fork Creek (elevation 2,990 $\mathrm{m})$. The fish were captured and released 50-310 $m$ upstream from a low-gradient reach that was bordered downstream by a beaver dam.

To determine habitat use during winter 19831984, we identified telemetry locations of fish in the stream during low flows in summer 1984. A transect was established at each location. When two or more locations were less than $5 \mathrm{~m}$ apart, we established a transect midway along the thalweg distance between the farthest upstream and farthest downstream locations. When a cluster of telemetry locations was present, we established transects at intervals equal to half the stream width upstream and downstream until the cluster of lo- cations was encompassed. These transects described the "home area" of the fish.

Across each transect, we determined water depth and predominant substrate class at a minimum of 10 equally spaced intervals, measured stream width, and determined a velocity index (the measured mean velocity at the point of maximum water depth across the transect). Predominant substrate size was visually estimated and classified: boulder ( $\geq 305 \mathrm{~mm}$ diameter), rubble (77$304 \mathrm{~mm})$, gravel $(5-76 \mathrm{~mm})$, and sand and silt ( $\leq 5 \mathrm{~mm}$ ).

Available habitat was measured along transects spaced at 5-m intervals encompassing the farthest upstream and downstream locations of fish within the study reach. Transect measurements were the same as those made for habitat use.

To determine habitat use in Nash Fork during winter 1984-1985, we plotted telemetry locations on a map made during summer 1984. The map encompassed two natural barriers to fish movement in the study reach - a beaver dam at the downstream end and a waterfall at the upstream end. Transects were established at 3-m intervals along a $392-\mathrm{m}$ baseline, and habitat variables were measured as described previously. Available habitat was taken as the sum of all transects for the mapped area.

Telemetry locations during winter 1984-1985 were referenced to points along the baseline by compass bearing and distance and plotted on the map. The data from the transect nearest the telemetry location were considered to be representative of the location. If a fish was found midway between transects, data for both transects were averaged. The linear index of electivity proposed by Strauss (1979) was used to assess brook trout selectivity for measured habitat features. The $95 \%$ confidence intervals were used to conclude whether the index differed from zero and if selection had occurred.

\section{Results}

\section{Stream Conditions}

Water temperature ranged from 0.0 to $1.0^{\circ} \mathrm{C}$ at the four study reaches between December 1983 and March 1984. From 23 September 1983 to 10 May 1984, conditions on the four reaches were relatively stable; cross-sectional area, wetted perimeter, water depth, and stream width decreased gradually with decreasing discharge. Average water depth decreased as much as $30 \%$, and trends were similar for wetted perimeter, wetted width, and 
Fish. Trans. $-700-B$... 8526F ... Gal. 22

surface area. Detailed descriptions are in Chisholm (1985).

Little stream habitat was physically excluded by surface ice. From October to December 1983, we found no ice at the highest site $(3,205 \mathrm{~m})$ and little at the next two highest sites $(3,120$ and $3,150 \mathrm{~m})$, where ice (maximum thickness $16 \mathrm{~cm}$ ) was found only near the stream bank at pool transects. Ice formation was more extensive at the lowest elevation $(2,993 \mathrm{~m})$, where the ice was as thick as 24 $\mathrm{cm}$ along the pool transect in December. Surface ice gradually diminished through the winter, persisting at the edge of the stream and often being separated from the water surface by an air gap.

Snow bridging across the stream reaches was first observed on 5 December 1983 and increased through the winter. Maximum snow depths at the four sites ranged from 1.3 to $4.3 \mathrm{~m}$; the lowest maximum was at the $2,993-\mathrm{m}$ reach and the highest at the 3,205-m reach. The entire stream width of the three reaches at or above $3,120 \mathrm{~m}$ was covered with snow after the initial accumulation in October 1983. At the 2,993-m reach, $6-100 \%$ of the stream width was covered by snow during winter, the percent increasing as maximum snow depth increased from 0.4 to $1.1 \mathrm{~m}$.

Winter stream conditions changed with lower elevation on the eastern slope of the Snowy Range in January 1985. Mean snow depth (logarithmic transformation) was significantly correlated with elevation ( $r=0.76-0.88 ; P=0.05$; Figure 1). In contrast, the log of mean surface ice depth on elevation was negatively correlated $(r=-0.65$ to $-0.79 ; P=0.05$; Figure 2). Habitat exclusion by surface ice formation also increased with decreasing elevation. Ice was essentially absent above $2,900 \mathrm{~m}$; whereas, at all reaches below $2,800 \mathrm{~m}$, it covered at least $40 \%$ of the total cross-sectional area. The highest proportion (52-67\%) of the crosssectional area was taken up by ice at riffle sites.

\section{Brook Trout Movement}

Seven fish were successfully tracked through the 1983-1984 winter; one radio-tagged fish was not located after release. Brook trout at elevations above $2,990 \mathrm{~m}$ were active during the winter (October-March); interpool movement was commonly recorded in the study reaches. Average movement of the seven fish between home areas or single locations was $86 \mathrm{~m}$ during the tracking period. Net movement (difference between maximum upstream and downstream locations) of five fish tracked for $152 \mathrm{~d}$ was downstream within the meadow area where they were radio tagged; move-

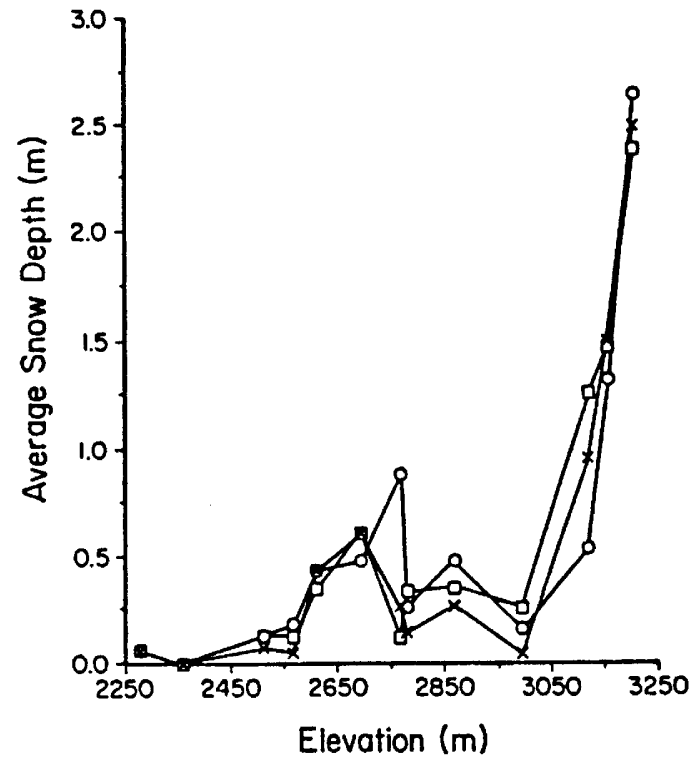

Figure 1.-Relation of mean snow depth to elevation at sampling sites on the eastern slope of the Snowy Range, Wyoming, January 1985: $\square=$ riffle; $x=$ transition from riffle to pool; $\mathrm{O}=$ pool.

ment of one fish was upstream within the meadow where it was tagged; and one remained throughout the winter in the same area of the meadow where it was tagged. The range of net distances moved

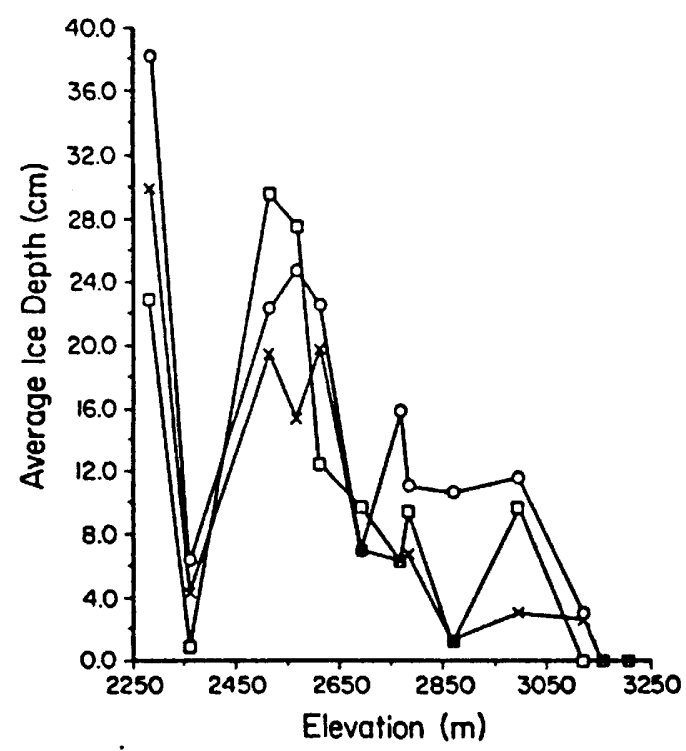

FIGURE 2.-Relation of mean surface ice thickness to elevation at sampling sites on the eastern slope of the Snowy Range, Wyoming, January 1985: $\square=$ riffle; $x=$ transition from riffe to pool; $O=$ pool. 

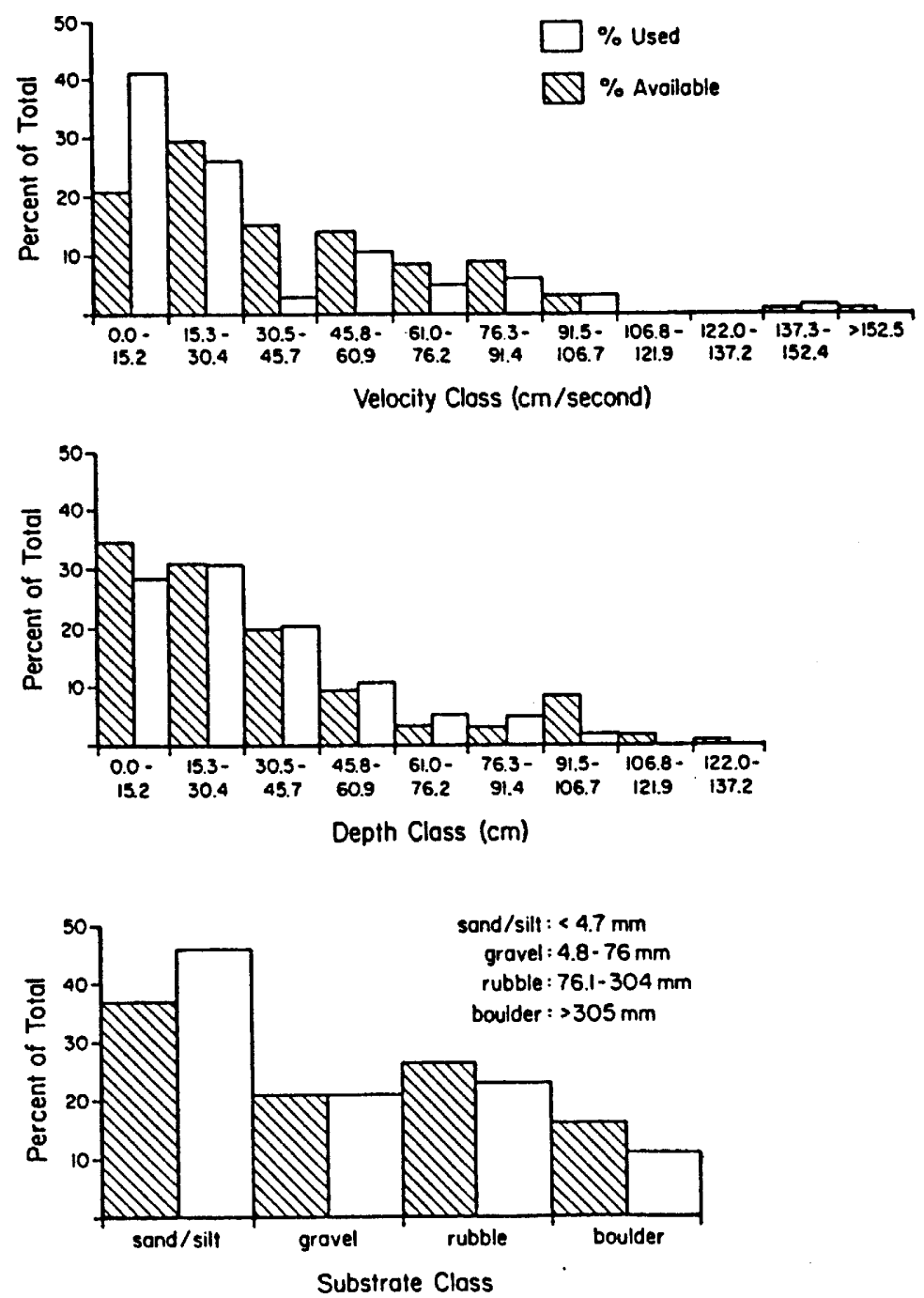

FIGURE 3. - Comparison of habitat available to habitat used by seven radio-tagged brook trout in Telephone Creek and Nash Fork Creek, Snowy Range, Wyoming, October 1983 to March 1984.

was 0-206 $\mathrm{m}$, all within the low-gradient reaches where the fish were originally captured and released.

During 1984-1985, downstream movement was observed for six of eight fish tracked for $127 \mathrm{~d}$. All these fish had been tagged and released in a high-gradient area. The six moved downstream 54-342 m (average movement, $163 \mathrm{~m}$ ) into a lowgradient beaver pond within 2 weeks (October 1984) after transmitters were implanted, and they remained active throughout the winter, moving from one end of the pond to the other. The net movements of two nearly sedentary fish that oc- cupied pools alongside the main channel in the high gradient area were only 33 and $36 \mathrm{~m}$.

\section{Habitat Selection}

Throughout the entire tracking period in 19831984 , even though five of seven fish moved downstream and one moved upstream, all individuals remained in the low-gradient meadow reaches where they were captured. The index of velocity indicated that there was selection in winter for areas (primarily pools) that had a maximum velocity of $15 \mathrm{~cm} / \mathrm{s}$ or less when measured during summer low flow (Figure 3). These low-velocity 
Fish. Trans. -700 -B .. 8526F ... Gal.-23

areas made up only $21 \%$ of the available habitat, but brook trout were located in them during $42 \%$ of the telemetry observations. The linear index of electivity supported this observation only for areas with a velocity index of $0-15 \mathrm{~cm} / \mathrm{s}$. No selection for depth or substrate classes was indicated. In these snow-covered areas brook trout were primarily found in water $0-30 \mathrm{~cm}$ deep, and at locations where substrate was predominately sand and silt.

During 1984-1985, when a range of stream gradients was available, fish selected low water velocities, deeper water, and sand-silt substrate (Figure 4). When data for all eight fish were combined, strong selection for areas with a velocity index of $15 \mathrm{~cm} / \mathrm{s}$ or less was shown; these areas made up $33 \%$ of the available habitat and were used $86 \%$ of the time. Strongest selection for these areas was shown by the six fish that moved downstream into the low-gradient reach containing a beaver pond (linear index of electivity range, $0.53-0.67$ ). The two fish that remained in the high-gradient reach showed selection for areas where the index of velocity was $15-67 \mathrm{~cm} / \mathrm{s}$ (linear index of electivity range, $0.13-0.35$ ). However, these fish were found primarily in pools next to the main current where velocity was less than that indicated by the velocity index for the transect.

Because six fish moved into the low-gradient, ponded reach, overall selection for deeper water $(30-107 \mathrm{~cm})$ and sand-silt substrate was also recorded in 1984-1985. The two fish which remained in the high-gradient reaches were selective for shallower water $(<46 \mathrm{~cm})$ and gravel-rubbleboulder substrates. When the amount of ice formation on the beaver pond was taken into consideration, the actual water depths available to the fish were similar to those available to fish in the meadow areas in 1983-1984 (selection, 15-30 cm) and to the two fish in the high-gradient areas in 1984-1985 (selection, 0.0-46 cm).

\section{Discussion}

Discharge was stable but had a declining trend during winter, thereby providing habitat stability in the high-altitude reaches. Because snow cover above $2,990 \mathrm{~m}$ was complete and extensive (depth, 1.3-4.2 m), loss of stream-bed heat was prevented, surface and anchor ice did not form, water temperatures were stable $\left(0.0-1.0^{\circ} \mathrm{C}\right)$, and a freeflowing channel remained under the snow in channels not impounded by beaver. Time-of-travel velocities determined by dye dilution at the four sites above $2,990 \mathrm{~m}$ during fall 1983 (before snow cov- er) and winter 1984 (after complete snow cover) were similar when adjusted for differences in disicharge. Channel roughness due to surface ice or slush did not appear to increase during winter.

Winter conditions in beaver-impounded reaches at high elevations (above $2,990 \mathrm{~m}$ ) were different from those in nonimpounded reaches. Although snow cover may prevent surface ice formation in stream channels, it has been found to facilitate the growth of white ice on alpine lakes and impounded water (Adams 1981). Extensive surface ice seen on the beaver pond $(2,990 \mathrm{~m})$ in $1984-1985$ probably resulted from pre-snow ice formation, wind action that controlled snow depths, and the growth of white ice.

The harshest winter conditions probably were at midelevation sites $(2,550-2,700 \mathrm{~m})$. Here, snow and surface ice cover were incomplete, and anchor ice was frequently observed. Maciolek and Needham (1952) stated that frazil and anchor ice could markedly affect stream life. Mortality of juvenile and adult fish, fish eggs, and benthos has been associated with such conditions by Tack (1938), Reimers (1957), and Reiser and Wesche (1979).

At the lowest elevation $(2,280 \mathrm{~m})$, extensive surface ice excluded $64-84 \%$ of the cross-sectional area from use by fish. Johnson et al. (1982) made similar observations on Wagonhound Creek (elevation $2,261 \mathrm{~m}$ ), also in Albany County, Wyoming. Our work suggests that at elevations greater than $2,990 \mathrm{~m}$ in the Snowy Range of Wyoming, anchor ice, slush, or surface ice does not impede flow during midwinter in stream reaches uninfluenced by beaver ponds. Thus, recommendations for winter streamflows can be based upon data collected by existing techniques for assessment during late summer or early fall low flow (Wesche and Rechard 1980; Bovee 1982). Habitat problems associated with water withdrawal would probably not be compounded by winter conditions at elevations above $2,990 \mathrm{~m}$ since habitat is not excluded by ice formation. However, the effect of winter water withdrawal at lower elevation sites may be severe because of probable habitat exclusion by surface and subsurface forms of ice and the lack of a suitable means for determining winter streamflow needs under these conditions.

In our study, altitude of reaches within a small watershed has been considered the primary independent variable influencing winter stream conditions. Numerous interrelated climatic, watershed, and channel characteristics may also contribute significantly to the degree to which snow bridging and surface ice formation occurs, both 

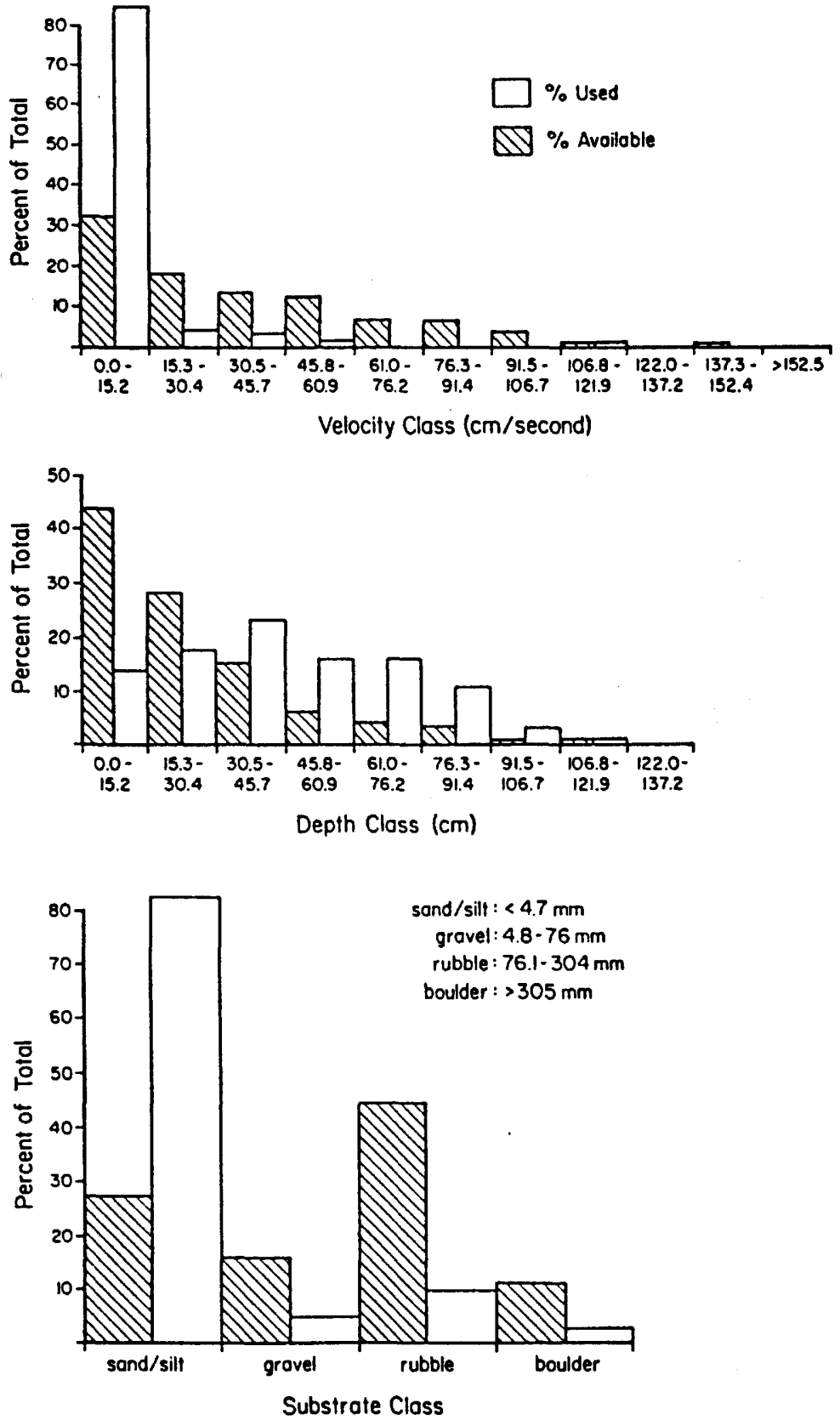

FIGURE 4. - Comparison of habitat available to habitat used by eight radio-tagged brook trout in a reach of Nash Fork Creek, Snowy Range, Wyoming, October 1984 to March 1985.

among and within watersheds. However, our study design did not allow testing of all such variables. It could be judged from our data that a narrow, deep channel would be more susceptible to snow bridging and subsequently would be better fish habitat, whereas a wide, shallow channel would not be as likely to drift over and lead to surface or anchor ice formation. Further study on the influence of channel shape on winter habitat conditions is needed because many human usesgrazing, channelization, logging-tend to create wider, shallower stream channels. Additional re- 
Fish. Trans. $-700-B$. . 8526F ... Gal. 24

search into the relationships among such physical channel variables could provide needed information regarding winter stream conditions and stream habitat management in northern latitudes.

We found that brook trout selected winter habitats with low velocity indices $(15 \mathrm{~cm} / \mathrm{s}$ or less) and relatively deep water. The study of winter microhabitat selection by Wichers (1978) showed a similar preference by brown trout Salmo trutta for low velocities. Our measure of velocity represented the velocity at the point of maximum depth across a transect; the velocity at the site occupied by the fish might have been less. These observations suggest that pools and beaver ponds with low current velocities are important habitat components for brook trout in mountain streams during winter.

\section{Acknowledgments}

We thank John Jacobson, Eric Featherston, Doug Inkley, Roger Schneidervin, Phillip Hubert, Andy George, Larry Dolan, Chris Goertler, and Carrie Frye for assistance in the field; Lyman McDonald and Victor Hasfurther for help in manuscript development; and the Wyoming Water Research Center at the University of Wyoming for financial support (grant number 2-92295).

\section{References}

Adams, W. P. 1981. Snow and ice on lakes. Pages 437466 in D. M. Gray and D. H. Male, editors. Handbook of snow: principles, processes, management and use. Pergamon, Elmsford, New York.

Benson, N. G. 1955. Observations on anchor ice in a Michigan trout stream. Ecology 36:529-530.

Bjornn, T. C. 1971. Trout and salmon movements in two Idaho streams as related to temperature, food, streamflow, cover, and population density. Transactions of the American Fisheries Society 100:423438.

Bovee, K. D. 1982. A guide to stream habitat analysis using the instream flow incremental methodology. U.S. Fish and Wildlife Service Biological Services Program FWS-OBS-82/26.

Buchanan, T. J., and W. P. Somers. 1969. Discharge measurement at gaging stations. Pages $31-40$ in Techniques of water resources investigations of the United States Geological Survey, book 3. U.S. Government Printing Office, Washington, D.C.

Chapman, D. W., and T. C. Bjornn. 1969. Distribution of salmonids in streams, with special emphasis on food and feeding. Pages 153-176 in T. G. Northcote, editor. Symposium on salmon and trout in - streams. H. R. MacMillan Lectures in Fisheries, University of British Columbia, Vancouver, Canada.

Chisholm, 1. M. 1985. Winter stream conditions and brook trout habitat use on the Snowy Range, Wyoming. Master's thesis. University of Wyoming. Laramie.

Cooper, E. L. 1953. Periodicity of growth and change of condition of brook trout (Salvelinus fontinalis) in three Michigan trout streams. Copeia 1953:107-114.

Hart, L. G., and R. C. Summerfelt. 1975. Surgical procedures for implanting ultrasonic transmitters into flathead catfish (Pylodictis olivaris). Transactions of the American Fisheries Society 104:56-59.

Hunt, R. L. 1969. Overwinter survival of wild fingerling brook trout in Lawrence Creek, Wisconsin. Journal of the Fisheries Research Board of Canada 26:1473-1483.

Hunt, R. L. 1974. Annual production by brook trout in Lawrence Creek during eleven successive years. Wisconsin Department of Natural Resources Technical Bulletin 82 .

Hynes, H. B. N. 1970 The ecology of running water. University of Toronto Press, Toronto.

Johnson, L. S., D. L. Wichers, T. A. Wesche, and J. A. Gore. 1982. Instream salmonid habitat exclusion by ice-cover. University of Wyoming, Wyoming Water Research Center, Water Resources Series 84, Laramic.

Maciolek, J. A., and P. R. Needham. 1952. Ecological effects of winter conditions on trout and trout foods in Convict Creek, California, 1951. Transactions of the American Fisheries Society 81:202-217.

McFadden, J. T. 1961. A study of the brook trout (Salvelinus fontinalis). Wildlife Monographs 7.

Needham, P. R., and A. C. Jones. 1959. Flow, temperature, solar radiation and ice in relation to activities of fishes in Sagehen Creek, California. Ecology 40:465-474.

Needham, P. R., J. W. Moffett, and D. W. Slater. 1945. Fuctuations in wild brown trout populations in Convict Creek, California. Journal of Wildlife Management 9:9-25.

Needham, P. R., and D. W. Slater. 1944. Survival of hatchery-reared brown and rainbow trout as affected by wild trout populations. Journal of Wildlife Management 8:22-36.

Rechard, P. A., R. McQuisten, and L. P. Perry. 1975. Glossary of selected hydrologic terms. University of Wyoming, Water Resources Research Institute, Water Resources Series 1, Laramie.

Reimers, N. 1957. Some aspects of the relation between stream foods and trout survival. California Fish and Game 43:43-69.

'Reiser, D. W., and T. A. Wesche. 1979. In situ freezing as a cause of mortality in brown trout eggs. Progressive Fish-Culturist 41:58-63.

Strauss, R. E. 1979. Reliability estimates for Ivlev's electivity index, the forage ratio, and a proposed linear index of food selection. Transactions of the American Fisheries Society 108:344-353.

Tack, E: 1938. Trout mortality from the formation of suspended ice crystals. Fischerei-Zeitung 41:42. (Reviewed by L. E. Wolf, 1938, Progressive FishCulturist 5[37]:26.)

Wesche, T. A. 1982. The Snowy Range Observatory: 
an update and review. University of Wyoming, $W y-$ oming Water Research Center, Water Resources Series 81, Laramie.

Wesche, T. A., and P. A. Rechard. 1980. A summary of instream flow methods for fisheries and related research needs. Eisenhower Consortium Bulletin 9.

Wichers, D. L. 1978. Telemetric determination of salmonid winter microhabitat occupation and move- ment in ice-covered streams. Master's thesis. University of Wyoming, Laramie.

Zippin, C. 1958. The removal method of population estimation. Journal of Wildlife Management 22:8290.

Received April 3, 1986 Accepted March 30, 1987 